\title{
In-Vitro Fermentation by Human Fecal Bacteria and Bile Salts Binding Capacity of Physical Modified Defatted Rice Bran Dietary Fiber*
}

\author{
Cheickna Daou1\#, Hui Zhang2, Camel Lagnika3, Oumarou Hama Moutaleb² \\ ${ }^{1}$ University of Sciences, Techniques and Technologies of Bamako (USTTB), Faculty of Sciences and Techniques \\ (FST)/Institute of Applied Sciences (ISA), Bamako, Mali \\ ${ }^{2}$ School of Food Science and Technology, Jiangnan University, Wuxi, China \\ ${ }^{3}$ Ecole Nationale des Sciences et Technique de Conservation et Transformation des Produits Agricoles de \\ Sakété, Université d'Agriculture de Kétou, Kétou, Benin \\ Email: ${ }^{\text {rimma504@yahoo.fr }}$
}

Received 2 March 2014; revised 5 April 2014; accepted 20 April 2014

Copyright (C) 2014 by authors and Scientific Research Publishing Inc.

This work is licensed under the Creative Commons Attribution International License (CC BY).

http://creativecommons.org/licenses/by/4.0/

(c) (i) Open Access

\section{Abstract}

Defatted rice bran dietary fiber (DRBDF) was modified by micronization, ultrasound, microwave and extrusion cooking. We investigated the impacts of these physical treatments on the fermentation ability and bile salts binding capacity of DRBDF. In-vitro fermentation by human fecal bacteria of modified fibers showed that the major fermentation products were propionic, acetate and butyrate acid. Fermentation of extruded fiber gave the highest amounts of propionic and acetic acid 135.76 and $25.45 \mathrm{mmol} / \mathrm{L}$ respectively, while, the fermented product with microwaved fiber had the highest butyric acid content $(10.75 \mathrm{mmol} / \mathrm{L})$. The amount of short-chain fatty acid increased from $12 \mathrm{~h}$ to $24 \mathrm{~h}$ and propionic acid was the predominant. On the other hand, in-vitro bile salts binding showed that extruded fiber had higher affinity with sodium deoxycholate and sodium chenodeoxycholate $(66.14 \%$ and $30.25 \%$ respectively) while microwaved fiber exhibited the highest affinity with sodium taurocholate $(14.38 \%)$. In the light of obtained results we can affirmed that these physical treatments significantly improved the fermentation products and bile salts binding capacity of DRBDF. Extrusion compared to the other physical treatment methods used in this study has greatly and positively influenced the fermentation and bile binding capacity of DRBDF.

*This is the extended version of the article title "Study on Functional Properties of Physically Modified Dietary Fibers Derived from Defatted Rice Bran”, Journal of Agricultural Science, Vol. 4, No. 9, 2012, pages 85-97, DOI:10.5539/jas.v4n9p85, ISSN 1916-9752 E-ISSN 1916-9760, Published by Canadian Center of Science and Education.

\#Corresponding author.

How to cite this paper: Daou, C., Zhang, H., Lagnika, C. and Moutaleb, O.H. (2014) In-Vitro Fermentation by Human Fecal Bacteria and Bile Salts Binding Capacity of Physical Modified Defatted Rice Bran Dietary Fiber. Food and Nutrition Sciences, 5, 1114-1120. http://dx.doi.org/10.4236/fns.2014.512121 


\section{Keywords}

\section{Defatted Rice Bran, Dietary Fiber, Physical Treatments, Modified Dietary Fiber, Fermentation, Bile Salts, Binding}

\section{Introduction}

The significance of dietary fiber of late is gaining increase acceptance due to its potential beneficial influence including control of gastrointestinal (GI) disorders, diabetes, obesity and cardiovascular diseases. However, such disorders have a very low incidence among people consuming recommended amount 25 - $30 \mathrm{~g} /$ day of fiber [1] [2]. Total dietary fiber (TDF) is a chemical complex having the ability to react and interact within food structure and human digestive system [3]. It can exert its influence on the gut directly and also possess indirect metabolic actions which alter the outline of digestion and absorption [4].

Dietary fiber has also the ability to affect the lipid metabolism. One possible mechanism of action that has been suggested is that dietary fiber binds bile salts and thus inhibits cholesterol absorption. Eastwood and Coworkers [5] first described the binding of intestinal bile salts to nonnutritive material in the small intestine of the rat. Later, they [6] confirmed the ability of nonabsorbed components of the diet to adsorb bile salts in vitro. Lignin was found to be very efficient in this respect. Other authors have also observed this ability of fiber to bind bile salts in vitro [7] [8].

The report of many Scientifics showed that the extent of fermentation of fiber is influenced by a number of factors, such as its water-solubility, chemical structure, lignifications, particle size, other components of the diet and the amount ingested. Processing of dietary fiber may also affect its degradation. Björck et al. [9] demonstrated that dietary fiber from extruded wheat flour was more extensively degraded in rats than dietary fiber of unprocessed wheat flour, and Wyman et al. [10] suggested that the fecal bulking effect of raw bran in man was more pronounced than that of cooked bran.

In this study, micronization, extrusion cooking, microwave and ultrasonic treatments were applied to defatted rice bran dietary fiber to change its structure and particles size which will be affected by its physico-chemical, physiological and fermentation ability.

The purpose of this study is to investigate the impact of these physical treatments on bile salts binding capacity and fermentation ability of defatted rice bran dietary fibers.

\section{Materials and Methods}

\subsection{Materials}

The defatted rice bran dietary fiber (DRBDF) was extracted according to the method of Cheickna \& Hui [11]. The extracted fiber was modified by different physical treatments: micronization, extrusion cooking, microwave and ultrasonic treatments according the methods described by Cheickna \& Hui [12].

\subsection{Methods}

\subsubsection{In-Vitro Fermentation of Modified DRBDF by Human Fecal Bacteria}

The modified DRBDF were fermented by a batch-culture technique that used fresh human fecal microflora [13]. To $0.5 \mathrm{~g}$ of each modified DRBDF and untreated DRBDF (as control), $40 \mathrm{~mL}$ of following medium was added: Trypticase, a pancreatic digest of casein USP $(5 \mathrm{~g} / \mathrm{L})$; minerals $\left(\mathrm{Na}_{2} \mathrm{HPO}_{4}, 5.7 \mathrm{~g} / \mathrm{L} ; \mathrm{KH}_{2} \mathrm{PO}_{4}, 6.2 \mathrm{~g} / \mathrm{L}\right.$; $\mathrm{MgSO}_{4} \cdot 7 \mathrm{H}_{2} \mathrm{O}, 0.6 \mathrm{~g} / \mathrm{L} ; \mathrm{CaCl}_{2} \cdot 2 \mathrm{H}_{2} \mathrm{O}, 13.2 \mathrm{~g} / \mathrm{L} ; \mathrm{MnCl}_{2} \cdot 4 \mathrm{H}_{2} \mathrm{O}, 10 \mathrm{~g} / \mathrm{L} ; \mathrm{CoCl}_{2} \cdot 6 \mathrm{H}_{2} \mathrm{O}, 1.0 \mathrm{~g} / \mathrm{L} ; \mathrm{FeCl}_{3} \cdot 6 \mathrm{H}_{2} \mathrm{O}, 8.0$ $\mathrm{g} / \mathrm{L})$.

The fibers to be studied were previously hydrated in the medium for $6 \mathrm{~h}$. $2 \mathrm{~mL}$ of reducing solution (cysteine hydrochloride, $6.25 \mathrm{~g} / \mathrm{L}$; $\mathrm{NaOH}, 1.6 \mathrm{~g} / \mathrm{L}$; and $\mathrm{Na}_{2} \mathrm{~S} \cdot 9 \mathrm{H}_{2} \mathrm{O}, 6.25 \mathrm{~g} / \mathrm{L}$ ) was added to each flask and carbon dioxide was admitted until resazurine added to the medium became colorless, indicating an anaerobic conditions. In all experiments once the reduction was achieved, a fresh fecal stool from human was used to prepare a $20 \%$ fecal solution by using phosphate buffer under anaerobic conditions. Each experimentation flask was inoculated with $10 \mathrm{~mL}$ of $20 \%$ fecal solution. The carbon dioxide was then adjusted to a pressure of $2 \mathrm{~cm}$ water and the flask 
contents were gently shaken at $37^{\circ} \mathrm{C}$ for 12 and $24 \mathrm{~h}$.

Two milliliter of sample was taken from each fermentation flask for analysis of short-chain fatty acids (SCFAs) and measurement of pH. SCFAs such as acetate, propionate, butyrate, isovalerate and caproic acids were measured by High performance liquid chromatography [HPLCAgilent 1100 Series, Waldbronn, Germany) with a C-18 column (YMC-PackODS-A, $5 \mu \mathrm{m}, 4.6 \mathrm{~mm} \times 150 \mathrm{~mm}$ )].

To determine the effects of fibers on stool weight, $5 \mathrm{~mL}$ of the fermentation contents were placed into dialysis bags (25 mm diameter) with molecular weight cut-off (MWCO 12,000 - 14,000), which were placed in $50 \mathrm{~mL}$ polyethylene glycol (PEG; MW 10,000) solution. This polyethylene solution produces an osmotic pressure of $0.2 \mathrm{MPa}$ [14]. After $72 \mathrm{~h}$ in the PEG solution, the bags were removed, gently blotted, and weight $\left(\mathrm{W}_{1}\right)$. The bags and the contents were then dried in an oven at $100^{\circ} \mathrm{C}$ overnight and the bags were reweighed $\left(\mathrm{W}_{2}\right)$. $\mathrm{A} \mathrm{bag}$ containing $5 \mathrm{~mL}$ of $1 \mathrm{~g}$ sodium azide/L was used as a control $\left(\mathrm{W}_{3}\right)$ and after drying overnight gave $\left(\mathrm{W}_{4}\right)$. The water held by each fermentation residue is $W_{1}-W_{3}$. The weight of fermentation residue holding the water is $W_{2}-W_{4}$. The water held by $1 \mathrm{~g}$ fermentation residue is therefore:

$$
\mathrm{WHC}(\mathrm{g} / \mathrm{g})=\left(\mathrm{W}_{1}-\mathrm{W}_{3}\right) /\left(\mathrm{W}_{2}-\mathrm{W}_{4}\right)
$$

\subsubsection{Bile Salts Binding Capacity of Modified Defatted Rice Bran Dietary Fibers}

Sodium cholate, sodium chenodeoxycholate, sodium deoxycholate, and sodium taurocholate were the used bile salts, to perform this study. The in-vitro binding procedure of modified DRBDF to bile salts was a modification of that by Yoshie-Stark and Wasche [15].

Each bile salt (as substrate) was dissolved in physiological saline ( $\mathrm{pH} 6.5$ ) to make $2 \mu \mathrm{mol} / \mathrm{mL}$ solutions. Forty milligrams of each modified and untreated DRBDF were added to each $5 \mathrm{~mL}$ bile salts solution, and the individual substrate solution without samples was used as blank. Cholestyramine, a bile acid binding anionic resin was the positive control. Then the tubes were incubated in shaking water bath at $37^{\circ} \mathrm{C}$ for $1 \mathrm{~h}$. Mixtures were centrifuged at $12,000 \mathrm{rpm}$ at $-4^{\circ} \mathrm{C}$ for $30 \mathrm{~min}$ in ultracentrifuge.

The supernatant was removed into a second set of tubes. An additional $1 \mathrm{~mL}$ saline solution was used to rinse out the incubation tubes and added to sediments, mixed well and centrifuged as before. The supernatant was removed and combined with the earlier supernatant. Aliquots of the pooled supernatant were frozen at $-20^{\circ} \mathrm{C}$ for bile salts analysis. Bile salts were analyzed using High performance liquid chromatography [HPLC Agilent 1100 Series, Waldbronn, Germany) with a C-18 column (YMC-PackODS-A, 5 m, $4.6 \mathrm{~mm} \times 150 \mathrm{~mm}$ )].

\subsection{Statistical Analysis}

All the analyses were carried in triplicate, and mean \pm standard deviation (SD) values have been presented. Data were statistically evaluated by one-way analysis of variance (ANOVA) using Statistical Program for Social Science (SPSS) (version 17) for significance $(\mathrm{p} \leq 0.05)$ and the Tukey test at $95 \%$ confidence level.

\section{Results and Discussion}

\subsection{In-Vitro Fermentation}

\subsubsection{Evolution of Short-Chain Fatty Acid}

The fermentation products, with carbohydrates as fermentation substrate, are mainly short-chain fatty acids and gases $\left(\mathrm{CO}_{2}, \mathrm{CH}_{4}\right.$ and $\left.\mathrm{H}_{2}\right)$ and these end products are either excreted in the stool or absorbed from the colon. Short chain fatty acids (SCFAs; acetic, propionic and butyric acid) are formed during bacterial fermentation of carbohydrates in the colon.

The interest in SCFA production is related to increasing body knowledge of the physiological effects of these acids. SCFAs are important anions in the colonic lumen and serve locally as nutrients for the mucosa cells, stimulating mucosal proliferation and blood flow. Especially butyric acid has been emphasized. It is the main energy substrate for the colonocytes and has been suggested to play a role in the prevention and treatment of diseases of the colonic mucosa, such as distal ulcerative colitis and cancer.

SCFA production decreases the luminal $\mathrm{pH}$, and may thereby, stimulate mineral absorption and reduce secondary bile acid formation in the colon. Colonic generation of SCFAs has also been related to systematic and metabolic effects, e.g. SCFAs may influence the motility along the gastrointestinal tract and propionic acid has been suggested to inhibit the cholesterol synthesis from acetic acid in the liver. 
Evolution of short-chain fatty acids (SCFA) produced after 12 and 24 h fermentation are shown in Table 1. The major SCFA produced were propionate, acetate, and butyrate, with smaller amounts of Isovaleric and caproic acids.

The amount of produced SCFA increased significantly with an increase of fermentation time for all treated fiber, but it was not significantly changed with untreated fiber. Extruded fiber yielded the largest amount of total SCFA, followed by ultrasonicated, microwaved, micronized and untreated DRB dietary fiber after $24 \mathrm{~h}$. While, untreated fiber yielded the greatest amount after $12 \mathrm{~h}$ and microwaved fiber the lowest. However, extruded fiber fermentation resulted in the greatest evolution of propionic and acetate acids $(135.76$ and $25.45 \mathrm{mmol} / \mathrm{L}$; respectively) and microwaved yielded in the highest evolution of butyric acid $(10.75 \mathrm{mmol} / \mathrm{L})$ after $24 \mathrm{~h}$.

Amongst produced SCFA, propionic acid was predominant followed by acetic and butyric acids. Averaged across all substrates, acetate, propionate, and butyrate were produced in the molar proportion: 14:80:6. The profiles of SCFA produced were comparable for all substrates. Fermentation of substrates in experiment resulted in greater molar proportion of propionic and lower molar proportions of acetate and butyrate than observed from fermentation of rye, oat and wheat bran fiber [16].

The content and distribution of SCFA depends on the fecal microflora, the type and amount of indigestible carbohydrate available [17]. The fermentability of fiber was also highly dependent of physico-chemical properties. Thus, soluble fiber fermented more readily than insoluble fiber and this latter create fecal bulk rather than contribute to SCFA production. Whereas, these physical treatments which improved the solubility of DRB fiber, could increased its fermentability (Table 1).

The molar distribution of acetic, propionic and butyric acids produced at fermentation of treated fiber showed higher amount of propionic acid. This high amount of propionic acid may be due to the increase of monomeric sugar arabinose and galactose which may be occurred during physical treatments. While, the lowest amount of acetic acid indicated that physical treatments did not contribute to increase of pectin substances. The lowest amount of butyric indicated the lack of starch in these physical modified fibers [18]-[20].

\subsubsection{Water Holding Capacity of Fermented Residues}

The water holding capacity after fermentation of physically treated DRBDF is shown in Table 2. It is the amount of water held by $1 \mathrm{~g}$ of the fermented residue.

Extruded fiber held the largest amount of water after 12 and $24 \mathrm{~h}$ fermentation, followed by untreated and microwaved fibers, micronized and ultrasonicated fibers, while untreated exhibited the lowest after $12 \mathrm{~h}$ at $\mathrm{p}<$ 0.05 .

The highest WHC of fermented residue of extruded fiber, the more degradable by bacteria, could be explained by an additional effect of an increase of WHC of bacterial cells. The lowest WHC for remained treated fiber might be due to the damage of cell structure of fiber occurred during the treatments.

WHC of fermented residues averaged 3.55 and $6.42 \mathrm{~g}\left(\mathrm{H}_{2} \mathrm{O}\right) / \mathrm{g}$ (fiber residue) for 12 and $24 \mathrm{~h}$; respectively. These averages were higher than that reported by Leslie [21]. The highest WHC had benefic effects for fecal bulking and fecal output and reduction of the intestinal transit time and prevent against colon rectal diseases.

Table 1. Evolution of SCFA after fermentation of DRB dietary fibers by human fecal bacteria.

\begin{tabular}{|c|c|c|c|c|c|c|c|}
\hline $\begin{array}{c}\text { Type of } \\
\text { Treatments }\end{array}$ & $\begin{array}{l}\text { Incubation } \\
\text { time (h) }\end{array}$ & $\begin{array}{c}\text { Acetic acid } \\
\text { mmol/L }\end{array}$ & $\begin{array}{l}\text { Propionic acid } \\
\text { mmol/L }\end{array}$ & $\begin{array}{c}\text { Butyric acid } \\
\mathrm{mmol} / \mathrm{L}\end{array}$ & $\begin{array}{c}\text { Isovaleric acid } \\
\mathrm{mmol} / \mathrm{L}\end{array}$ & $\begin{array}{c}\text { Caproic acid } \\
\mathrm{mmol} / \mathrm{L}\end{array}$ & $\begin{array}{c}\text { Total SCFA } \\
\mathrm{mmol} / \mathrm{L}\end{array}$ \\
\hline \multirow{2}{*}{ Untreated } & 12 & 19.89 & 107.8 & 5.42 & 1.61 & 7.2 & 141.92 \\
\hline & 24 & 19..91 & 109.35 & 5.87 & 1.64 & 7.42 & 144.19 \\
\hline \multirow{2}{*}{ Micronization } & 12 & 17.41 & 98.67 & 4.56 & 3.92 & 6.88 & 131.44 \\
\hline & 24 & 19.19 & 105.72 & 7.6 & 5.47 & 8.36 & 146.34 \\
\hline \multirow{2}{*}{ Ultrasonic } & 12 & 21.01 & 103.96 & 5.56 & 2.75 & 3.93 & 137.21 \\
\hline & 24 & 22.38 & 130.7 & 9.33 & 2.36 & 4.5 & 169.27 \\
\hline \multirow{2}{*}{ Microwave } & 12 & 7.4 & 53.6 & 1.64 & ND & 2.35 & 64.99 \\
\hline & 24 & 21.55 & 123.62 & 10.75 & ND & 7.15 & 163.07 \\
\hline \multirow{2}{*}{ Extrusion } & 12 & 1.47 & 121.8 & 5.87 & ND & ND & 129.14 \\
\hline & 24 & 25.45 & 135.76 & 7.19 & ND & 3.64 & 172.04 \\
\hline
\end{tabular}


Table 2. WHC of physical treated DRB dietary fibers after fermentation by human fecal bacteria.

\begin{tabular}{|c|c|c|c|c|c|c|c|}
\hline & & Control & Untreated & Micronization & Ultrasonic & Microwave & Extrusion \\
\hline \multirow{2}{*}{$\begin{array}{l}\text { Dry weight } \\
\text { residue (g) }\end{array}$} & $12 \mathrm{~h}$ & $0.14 \pm 0.033 \mathrm{abc}$ & $0.20 \pm 0.03 c d$ & $0.18 \pm 0.058 b c d$ & $0.19 \pm 0.013 \mathrm{~cd}$ & $0.18 \pm 0.032 \mathrm{bcd}$ & $0.23 \pm 0.032 \mathrm{~d}$ \\
\hline & $24 \mathrm{~h}$ & $0.11 \pm 0.011 a$ & $0.18 \pm 0.029 b c d$ & $0.19 \pm 0.036 \mathrm{~cd}$ & $0.12 \pm 0.067 \mathrm{ab}$ & $0.16 \pm 0.018 \mathrm{abcd}$ & $0.22 \pm 0.084 d$ \\
\hline \multirow{2}{*}{$\begin{array}{l}\text { WHC } \\
\text { (g/g) }\end{array}$} & $12 \mathrm{~h}$ & $2.84 \pm 0.40 \mathrm{~b}$ & $1.55 \pm 0.36 a$ & $1.99 \pm 0.36 a b$ & $3.16 \pm 0.50 \mathrm{~b}$ & $5.32 \pm 0.69 \mathrm{~cd}$ & $5.73 \pm 0.32$ cde \\
\hline & $24 \mathrm{~h}$ & $5.11 \pm 0.44 c$ & $6.54 \pm 0.28 \mathrm{ef}$ & $6.29 \pm 0.5$ cde & $5.13 \pm 0.1 \mathrm{c}$ & $6.45 \pm 0.39$ de & $7.68 \pm 0.15 f$ \\
\hline \multirow{2}{*}{$\begin{array}{l}\text { Total water } \\
\text { held by residue } \\
\text { (g) }\end{array}$} & $12 \mathrm{~h}$ & $1.16 \pm 0.1 \mathrm{ab}$ & $0.74 \pm 0.17 a$ & $0.9 \pm 0.17 \mathrm{ab}$ & $1.47 \pm 0.27 b c$ & $2.43 \pm 0.39$ de & $2.85 \pm 0.19 \mathrm{e}$ \\
\hline & $24 \mathrm{~h}$ & $1.94 \pm 0.11 \mathrm{~cd}$ & $2.99 \pm 0.28 \mathrm{e}$ & $2.92 \pm 0.4 \mathrm{e}$ & $2.02 \pm 0.6 \mathrm{~cd}$ & $2.79 \pm 0.7 e$ & $3.80 \pm 0.3 f$ \\
\hline
\end{tabular}

There is no significant difference between the values with the same letter for the same property.

\subsection{3. pH Variation During Fermentation}

During $24 \mathrm{~h}$ fermentation the $\mathrm{pH}$ decreased from 6.36 to 5.49 (Figure 1). There was a significant decrease in $\mathrm{pH}$ during the first $12 \mathrm{~h}$ while $\mathrm{pH}$ almost did not change after $12 \mathrm{~h}$. However, the production of SCFA increased significantly after $12 \mathrm{~h}$. thus and there was not highly correlation between $\mathrm{pH}$ and amount of produced SCFA. Karppinen [16] also concluded the same.

\subsection{In-Vitro Binding of Bile Salts by Different Physical Modified DRB Dietary Fibers}

The binding capacities of sodium deoxycholate, sodium taurocholate, and sodium chenodeoxycholate are shown in Figure 2.

Sodium deoxycholate was strongly bound by all fibers treated and untreated. Treated fibers except microwaved fibers showed a higher binding capacity compared to untreated while, but their binding capacity was lower than control (Cholestyramine 88.77\%). Extruded fiber showed the highest binding capacity followed by ultrasonicated, micronized, untreated and microwaved (66.14\%, 65.50\%, 59.47\%, 51.15\% and 45.60\%; respectively).

Sodium taurocholate was the salt against which fibers except control showed a minimal affinity. Microwaved fiber had shown the highest binding capacity (14.38\%) compared to other fibers followed by extruded (11.39\%), untreated (2.58\%), and ultrasonicated (1.87\%). Micronized fiber showed the lowest sodium taurocholate binding capacity $(0.35 \%)$.

Sodium chenodeoxycholate was highly bounded by physical treated fiber than untreated (7.19\%) and the impact of extrusion fibers was higher than other treatments followed by micronization, microwave and ultrasonic (30.28\%, 28.35\%, 27.03\% and 20.18\%; respectively).

Among the fibers, extruded fiber showed higher bile salts (especially sodium deoxycholate and sodium chenodeoxycholate) binding capacity than others. Sodium deoxycholate a secondary cholate with the most hydrophobicity produced by microorganism, and sodium chenodeoxycholate a primary bile acid produced by the body are thought to be involved in the etiology and development of colorectal cancer and other diseases [22] [23].

Chenodeoxycholate can dissolve gall-stone, and the synthesis of bile acid from cholesterol is adjusted by their concentration in the liver [24].

The presence of extruded or other physical modified fibers in intestine can decrease not only the enterohepatic circulation of bile acids, but also their contact with colorectal mucosa through the binding effect. Therefore, the consumption of extruded or other physical treated fiber might prevent against hypercholesterolemia, gall-stone and colorectal cancer at the same time.

Furthermore, sodium chenodeoxycholate and deoxycholate were reported as the special ligands offarnesoid $\mathrm{X}$ receptor (FXR) a kind of orphan nuclear receptor regulating the expression of cholesterol 7 Alpha-hydroxylase (CYP7A1), the rate-limiting enzyme in bile acid biosynthesis, and the intestinal bile acid-binding protein (I-BABP), a cytosolic protein that serves as a component of bile acid transport system in the ileal enterocytes [23]. Thus, the decrease of the concentration of deoxycholate in the intestine and chenodeoxycholate in the liver and intestine by ingestion extruded or other physical treated fibers might influence the activation or even the gene expression of FXR, and then regulate the homeostasis of cholesterol consequently. 


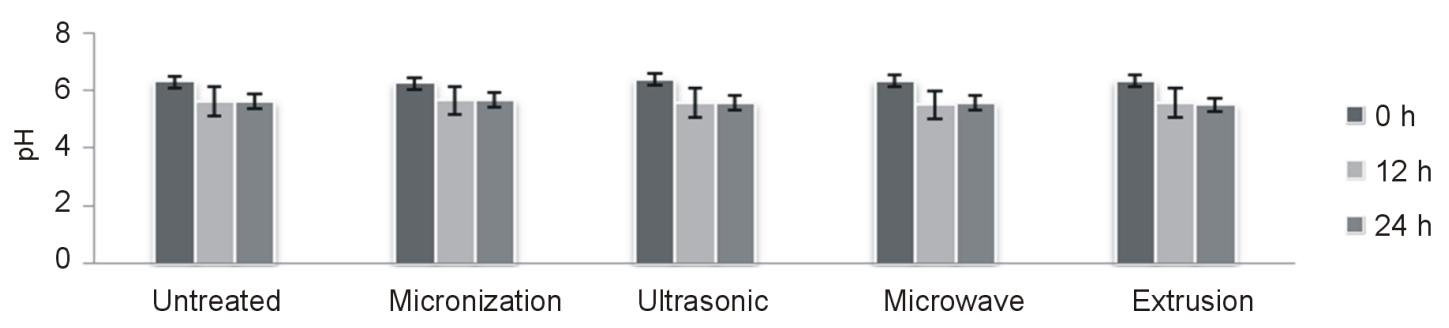

Figure 1. Variation of pH during in-vitro fermentation.

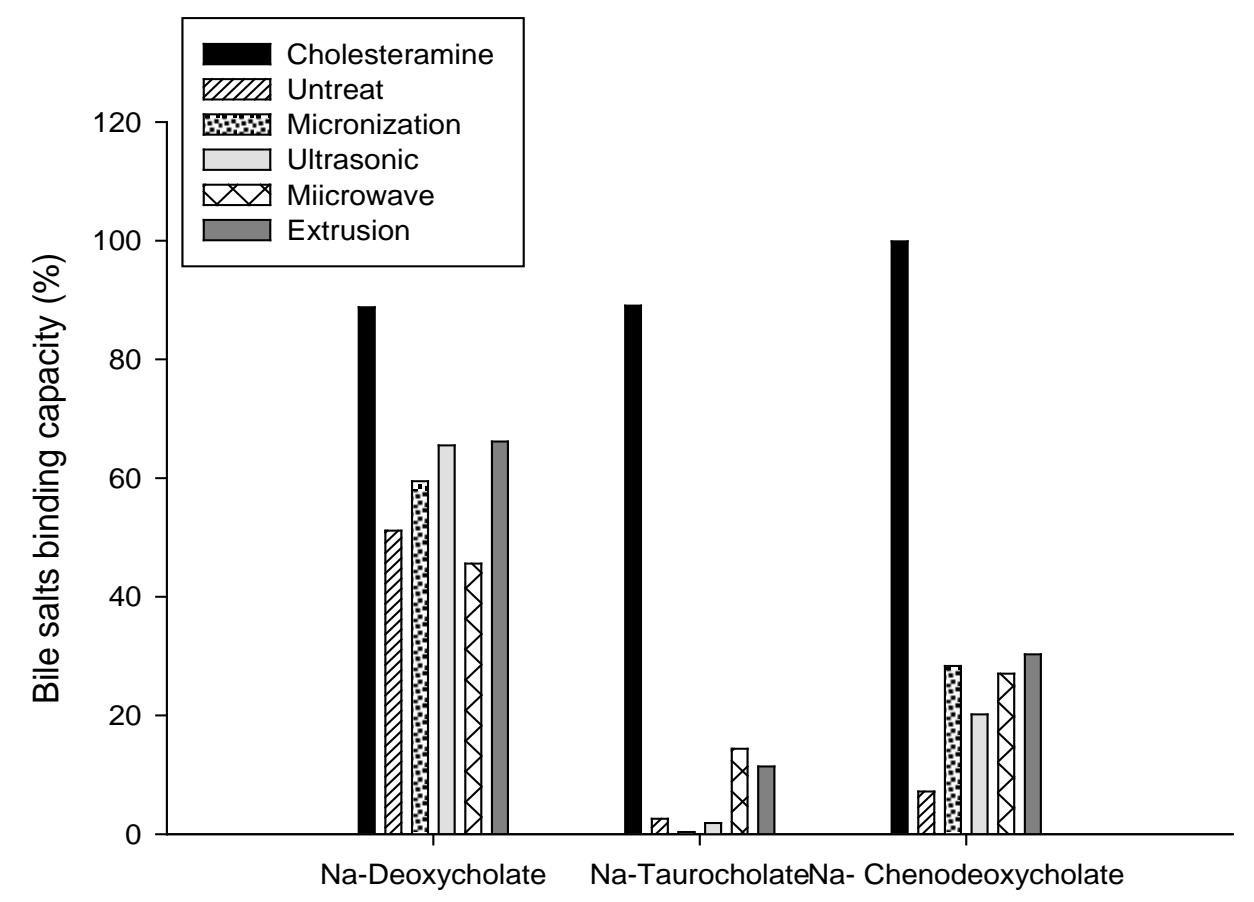

Figure 2. Bile salts binding capacity of physical modified dietary fibers from defatted rice bran.

\section{Conclusions}

The study confirmed that physically modified DRBDF have reduced the glucose breakdown rate and adsorption hence avoiding an increase in blood glucose level. The physical treatments (particular extrusion) significantly improved SCFA (propionic acid) production after $24 \mathrm{~h}$ fermentation by human fecal bacteria and increased WHC of fermented residues, thus, inhibit cholesterol synthesis from acetic acid in the liver, reduce secondary bile acid formation, improve fecal bulking, moisture and stool output, and decrease intestinal transit time and prevent against colon rectal diseases.

The physically treated DRBDF showed high affinity with sodium deoxycholate and chenodeoxycholate while, their affinity was lower with sodium taurocholate. Extruded fiber has the highest binding capacity against sodium deoxycholate and chenodeoxycholate while, microwaved fiber exhibited the highest against sodium taurocholate. The physical treatments improved not only physicochemical and functional and technological properties of defatted rice bran dietary fiber but its physiological properties.

\section{References}

[1] Sreenath, H.K., Sudarshanakrishna, K.R., Prasad, N.N. and Santhanam, K. (1996) Characteristics of Some Fibers Incorporated Cake Preparations and Their Dietary Fibre Content. Starch/Starke, 48, 72-76. http://dx.doi.org/10.1002/star.19960480208

[2] Sangnark, A. and Noomhorm, A. (2004) Effect of Dietary Fibre from Sugarcane Bagasse and Sucrose Esteron Doughand Bread Properties. LWT_Food Science and Technology, 37, 697-704. 
http://dx.doi.org/10.1016/j.lwt.2004.02.015

[3] Valiente, C., Molla, E., Martin-Cabrejas, M.M., Lopez-Andreu, F.J. and Esteban, R.M. (1996) Cadmium Binding Capacity of Cocoa and Isolated Total Dietary Fibre under Physiological pH Conditions. Journal of the Science of Food and Agriculture, 72, 476-482. http://dx.doi.org/10.1002/(SICI)1097-0010(199612)72:4<476::AID-JSFA682>3.0.CO;2-M

[4] Schneeman, B.O. (1998) Dietary Fibre and GI Function. Nutrition Research, 18, 625-632. http://dx.doi.org/10.1016/S0271-5317(98)00049-9

[5] Eastwood, M.A. and Boyd, G.S. (1967) The Distribution of Bile Salts along the Small Intestine of Rats. Biochimica et Biophysica Acta (BBA), 137, 393-396. http://dx.doi.org/10.1016/0005-2760(67)90116-6

[6] Eastwood, M.A. and Hamilton, D. (1968) Studies on the Adsorption of Bile Salts to Non-Absorbed Components of Diet. Biochimica et Biophysica Acta (BBA), 152, 165-173. http://dx.doi.org/10.1016/0005-2760(68)90018-0

[7] Bahner, J. and Zilversmit, D.B. (1974) Effects of Dietary Roughage on Cholesterol Absorption, Cholesterol Turn over and Steroid Excretion in the Rat. Journal of Nutrition, 104, 1319-1328.

[8] Birkner, H.J. and Kern Jr., F. (1974) In Vitro Adsorption of Bile Salts to Food Residues, Salicylazosulfapyridine, and Hemicellulose. Gastroenterology, 67, 237-244.

[9] Björck, I., Nyman, M. and Asp, N.-G. (1984) Extrusion Cooking and Dietary Fiber. Effect on Dietary Fiber Content and on Degradation in the Rat Intestinal Tract. Cereal Chemistry, 61, 174-179.

[10] Wyman, J.B., Heaton, K.W., Manning, A.P. and Wicks, A.C.B. (1976) The Effect on Intestinal Transit and the Feces of Raw and Cooked Bran in Different Doses. American Journal of Clinical Nutrition, 29, 1474-1479.

[11] Daou, C. and Zhang, H. (2013) Optimization of Processing Parameters for Extraction of Total, Insoluble and Soluble Dietary Fibers of Defatted Rice Bran. Emirates Journal of Food and Agriculture, 25, 562-575.

[12] Daou, C. and Zhang, H. (2012) Study on Functional Properties of Physically Modified Dietary Fibers Derived from Defatted Rice Bran. Journal of Agricultural Science, 4, 85-97.

[13] Goerink, H.K. and Van Soest, P.J. (1970) In-Vitro Rumen Digestibility Determination. Agricultural Handbook No. 379, US Government Printing Office, Washington DC.

[14] Robertson, J.A. and Eastwood, M.A. (1981) A Method to Measure the Water-Holding Properties of Dietary Fibre Using Suction Pressure. The British Journal of Nutrition, 46, 247-255.

[15] Yoshie-Stark, Y. and Wasche, A. (2004) In Vitro Binding of Bile Acids by Lupin Protein Isolates and Their Hydrolysates. Food Chemistry, 88, 179-184. http://dx.doi.org/10.1016/j.foodchem.2004.01.033

[16] Karppinen, S., Liukkonen, K., Aura, AM., Forssell, P. and Poutanen, K. (2000) In Vitro Fermentation of Poly- saccharides of Rye, Wheat and Oat Brans and Inulin by Human Faecal Bacteria. Journal of the Science of Food and Agriculture, 80, 1469-1476. http://dx.doi.org/10.1002/1097-0010(200008)80:10<1469::AID-JSFA675>3.0.CO;2-A

[17] Moore, W.E. and Holdeman, L.V. (1974) Human Fecal Flora: The Normal Flora of 20 Japanese-Hawaiians. Applied Microbiology, 27, 961-979.

[18] Englyst, H.N., Hay, S. and Macfarlane, G.T. (1987) Polysaccharide Breakdown by Mixed Population Populations of Human Faecal Bacteria. FEMS Microbiology Letters, 45, 163-171. http://dx.doi.org/10.1111/j.1574-6968.1987.tb02352.x

[19] McBurney, M.I. and Thompson, L.U. (1987) Effect of Human Faecal Inoculum on in Vitro Fermentation Variables. British Journal of Nutrition, 58, 233-243. http://dx.doi.org/10.1079/BJN19870091

[20] Berggren, A.M., Björck, I.M., Nyman, E.M. and Eggum, B.O. (1993) Short-Chain Fatty Acid Content and pH in Caecum of Rats Given Various Sources of Carbohydrates. Journal of the Science of Food and Agriculture, 63, 397406.

[21] Bourquin, L.D., Titgemeyer, E.C. and Fahey Jr., G.C. (1996) Fermentation of Various Dietary Fiber Sources by Human Faecal Bacteria. Nutrition Research, 16, 1119-1131. http://dx.doi.org/10.1016/0271-5317(96)00116-9

[22] Liu, J.-T., Yu, B., Hong, W.-B. and Xu, S.-H. (1993) The Pharmacologic Effect of 5-fu and the Change of the Intracellular Bile Acid Activities of Colon Cancer. Chinese Pharmacological Bulletin, 9, 386-389.

[23] Parks, D.J., Blanchard, S.G., Bledsoe, R.K., Chandra, G., Consler, T.G., Kliewer, S.A., et al. (1999) Bile Acids: Natural Ligands for an Orphan Nuclear Receptor. Science, 284, 1365-1368. http://dx.doi.org/10.1126/science.284.5418.1365

[24] Zhao, D.-L. (1998) Biochemistry of Liver and Gall Bladder. In: Wei, Y., Huang, Y.-S. and Huang, Q.-T., Eds., Medical Biochemistry, 3rd Edition, World Publishing Corp., Beijing, 360-375. 
Scientific Research Publishing (SCIRP) is one of the largest Open Access journal publishers. It is currently publishing more than 200 open access, online, peer-reviewed journals covering a wide range of academic disciplines. SCIRP serves the worldwide academic communities and contributes to the progress and application of science with its publication.

Other selected journals from SCIRP are listed as below. Submit your manuscript to us via either submit@scirp.org or Online Submission Portal.
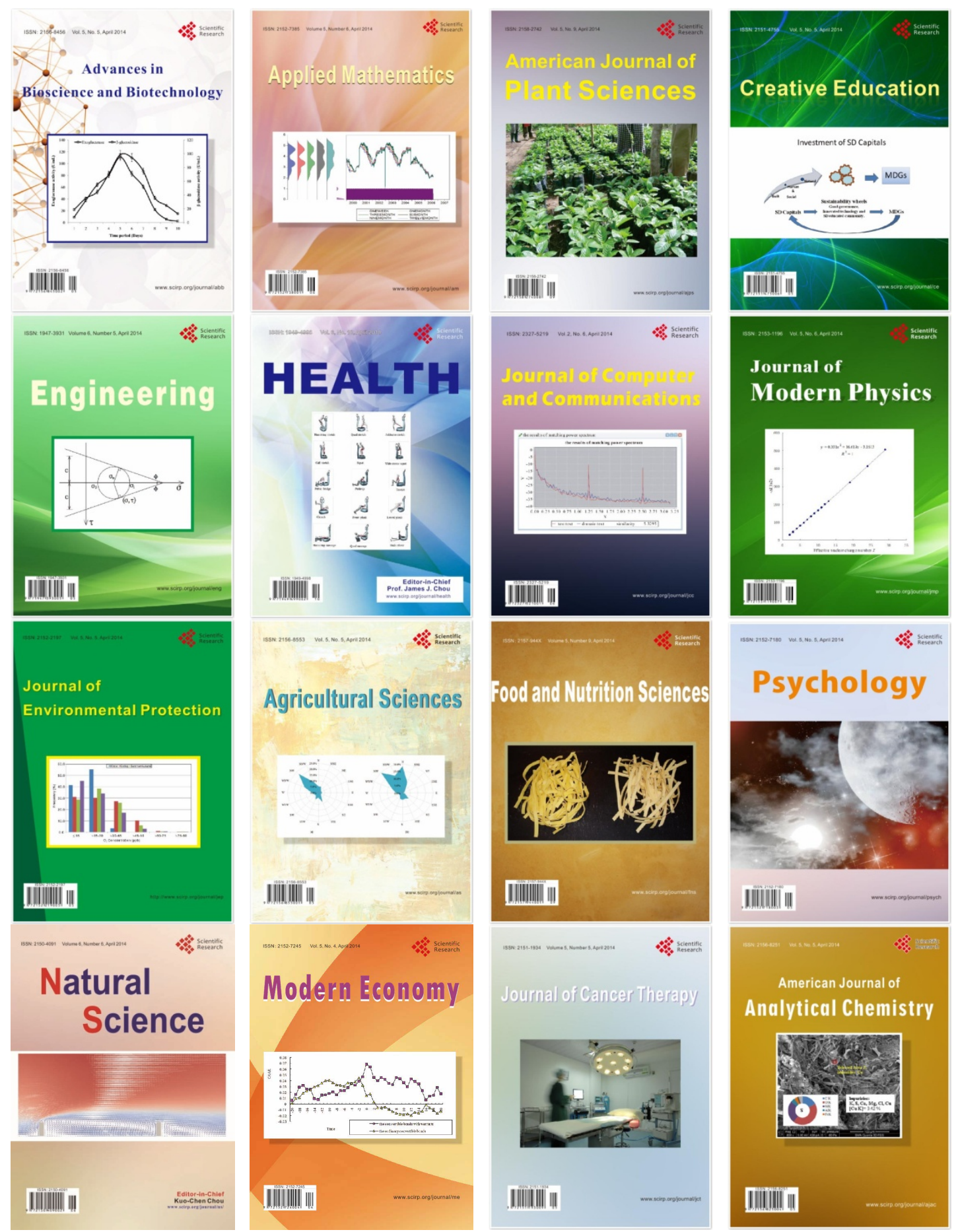